\title{
Detection of Uropathogenic Virulence Genes in Escherichia coli isolated from Urine Samples of Children under Five Years
}

\author{
Ilham S. Banno ${ }^{1}$, Ali F. Ahmed ${ }^{2}$ \\ Biology Department, College of Education for Pure Science, Ibn, AL-Haythum, University of Baghdad
}

\begin{abstract}
Escherichia coli is the predominant pathogen causing urinary tract infection(UTI).A total of 72 uropathogenic E,coli strains were isolated from clinical samples were taken from children with (UTI), whome they were under the age of five years, male and female taken from Baghdad hospitals in the period from 1/11/2014 to 28/2/2015. The study results showed that the infection in urinary tract of female were 39 isolates $54.2 \%$ of and that of males were 33 isolates $45.8 \%$. All isolates were identified according to morphological and biochemical tests and results were confirmed by Api $20 E$ system. Polymerase chain reaction (PCR) was used to find out two types of adhesion factors, Fim $(H)$ and Pap $G$ alleles genes, as they were the cause of the most common (UTI)s by using specialist primers for each gene. Results showed the existence of Fim $(H)$ gene was $100 \%$, while Pap $G(I)$ gene $19.4 \%$, Pap G(lll) gene 38.8\%, and the results of the test of Pap G(ll) gene were negative to all isolates.
\end{abstract}

Keywords: Escherichia coli, urinary tract infection

\section{Introduction}

Urinary tract infection (UTI) is among the most common bacterial infectious diseases encountered at all ages. Escherichia coli is being the etiologic agent in 50-80\%. Therefore, it is an important public health problem $(1, \& 2)$.Many virulence factors contribute to the pathogenicity of these E.coli strains, which are termed uropathogenic E.coli(UPEC)(3). In ascending infections, fecal bacteria colonize the urethra and spread up the urinary tract to the bladder as well as to the kidneys causing pyelonephritis(4) or the prostate in males. Because woman have a shorter urethra than men, they are 14 times more likely to suffer from an ascending UTI(1). Uropathgenic $E$. coli use $\mathrm{P}$ fimbriae (pyelonephritis-associated pili) to bind urinary tract urothelial cells and colonize the bladder(5). Many adhesive factors are seen in E.coli, they play a major role in the colonization of E.coli in different tissues of human body(6). Urovirulence factors of E.coli analysed by molecular methods are useful markers for detection of uropathogenic E.coli isolates(7).The polymearas chain reaction(PCR) is a powerful technique that has rapidly become one of the most widely used techniques in molecular biology because it is quick, inexpensive and simple(8). The aim of this study to detect genes encoding type 1 fimbriae $\operatorname{Fim}(H)$, and pili associated with pyelonephritis $\operatorname{Pap} G$ alleles.

\section{Material and Methods}

Isolation of bacteria
In this study, 110 urine samples were obtained from children with urinay tract infection, whome they were under the age of five years, male and female taken from three kids hospitals in baghdad city( Ibn Al-balady hospital for children, Al-Imamayn Al-Khademayn Teaching hospital and Al-A 'lwayya hospital for children), in the period from $1 / 11 / 2014$ to $28 / 2 / 2015$. The midstream urine sample collected from all patients. $0.01 \mathrm{ml}$ of urine cultured on MacConky agar and Eosin Methylen Blue(EMB). The isolation and identification of E.coli were performed on the basis of culture characteristics ( colonies phenotypic, Gram stain and biochemical tests according to (9) and confirmed by the Api 20E system(BioMerieux, France).

Bacterial culture and DNA extraction : E.coli strains were grown in Tryptic soy brith at $37^{\circ} \mathrm{C}$ overnight, DNA extraction of E.coli isolates was performed using (Geneaid kit).

\section{PCR amplification}

Specific primers which were provided in a lyophilized form by Bioneer(Korea), dissolved in sterile DDistilled water to give a final concentration of $100 \mathrm{pmol} / \mu \mathrm{l}$ as recommended by provider and stored in deep freezer until used in PCR amplification. Primers were used for detecting and amplify sequences of E.coli adhesion factors the $\operatorname{Fim}(H)$ gene and Pap $G$ gene alleles (1, 1l, 1ll). Details of primers sequences according to( 10), shown in Table( 1). PCR Master Mix contents was provided by the supplier(Bioneer) were listed in table(2).

Table 1: Oligonucleotide primers sequence used for PCR amplification of specific gene

\begin{tabular}{|c|c|c|c|}
\hline \multirow{2}{*}{$\left.\mathbf{5}^{\prime}-\mathbf{3}^{\prime}\right)($ Fim $(h)$} & F: & TGC AGA ACG GAT AAG CCG TGG & \multirow{2}{*}{509 bp } \\
\cline { 2 - 3 } & R: & GCA GTC ACC TGC CCT CCG GTA & \\
\hline \multirow{2}{*}{ pap G allel I $\left(5^{\prime}-3^{\prime}\right)$} & F: & TCG TGC TCA GGT CCG GAA TTT & \multirow{2}{*}{$461 \mathrm{bp}$} \\
\cline { 2 - 3 } & R: & TGG CAT CCC CCA ACA TTA TCG & \\
\hline pap G allel II $\left(5^{\prime}-3^{\prime}\right)$ & F: & GGG ATG AGC GGG CCT TTG AT & \multirow{2}{*}{$190 \mathrm{bp}$} \\
\cline { 2 - 3 } & R: & CGG GCC CCC AAG TAA CTC & \\
\hline pap G allel III $\left(5^{\prime}-3^{\prime}\right)$ & F: & GGC CTG CAA TGG ATT TAC CTG G & \multirow{2}{*}{$258 \mathrm{bp}$} \\
\cline { 2 - 3 } & R: & CCA CCA AAT GAC CAT GCC AGA & \\
\hline
\end{tabular}

Volume 6 Issue 7, July 2017 www.ijsr.net 


\section{International Journal of Science and Research (IJSR) \\ ISSN (Online): 2319-7064}

Index Copernicus Value (2015): 78.96 | Impact Factor (2015): 6.391

Table 2: PCR Master Mix provided from Bioneer

\begin{tabular}{|l|l|c|}
\hline Volum $\mu \mathrm{l}$ & Material & \\
\hline $1 \mathrm{U}$ & Top DNA polymerase & 1 \\
\hline 10 & Tris- $\mathrm{HCl}, \mathrm{pH}=9$ & 2 \\
\hline 250 & $\mathrm{dNTPs}(\mathrm{dATP}, \mathrm{dCTP}, \mathrm{dGTP}, \mathrm{dTTP})$ & 3 \\
\hline 30 & $\mathrm{KCl}$ & 4 \\
\hline 1.5 & $\mathrm{MgCl}_{2}$ & 5 \\
\hline & Stabilizer and tracking dye & 6 \\
\hline
\end{tabular}

\section{PCR assay}

All 72 E.coli isolates were analyzed by PCR. To each premix tube, the following reagents were added; $2 \mu 1$ of each of forwarded and Reverse primers, $5 \mu 1$ of DNA samples, and the volum adjusted to $20 \mu \mathrm{l}$ by adding sterilized double distilled water. Table (3) showed program detection for $\operatorname{Fim}(H)$ gene fragment and Table(4) showed program detection for $\operatorname{Pap}(G)$ gene allels by PCR cycling conditions. The amplification was carried out in a ESCO Thermo cycler machine model 5000. A10 $\mu 1$ aliquot of the PCR product underwent gel electrophoresis on $1 \%$ agarose, followed by staining with ethidium bromide solution. Amplified DNA fragments of specific sizes were detected by UV- induced fluorescence, and the size of the amplicons was estimated by comparing them with the 100bp DNA ladder(Promega) included on the same gel.

Table 3: PCR amplification program for $\operatorname{Fim}(H)$ gene

\begin{tabular}{|c|c|c|c|}
\hline $\begin{array}{c}\text { No. of } \\
\text { cycle }\end{array}$ & $\begin{array}{c}\text { Time } \\
(\mathrm{min})\end{array}$ & $\begin{array}{c}\text { Temperature } \\
C^{\boldsymbol{o}}\end{array}$ & stage \\
\hline 1 & 5 & 94 & DNA Intial Denaturation \\
\hline \multirow{3}{*}{30} & 1 & 94 & DNA Denaturation \\
\cline { 2 - 4 } & 1 & 60 & Annealing \\
\cline { 2 - 4 } & 1 & 72 & Extention \\
\hline 1 & 7 & 72 & Final Extention \\
\hline
\end{tabular}

Table 4: PCR amplification program for $\operatorname{Pap}(G)$ alleles

\begin{tabular}{|c|c|c|c|}
\hline $\begin{array}{c}\text { No. of } \\
\text { cycle }\end{array}$ & $\begin{array}{c}\text { Time } \\
(\mathrm{min})\end{array}$ & $\begin{array}{c}\text { Temperature } \\
\mathrm{C}^{\mathbf{o}}\end{array}$ & stage \\
\hline 1 & $4^{\mathbf{o}}$ & 94 & DNA Intial Denaturation \\
\hline \multirow{2}{*}{30} & 1 & 94 & DNA Denaturation \\
\cline { 2 - 4 } & 2 & 60 & Annealing \\
\cline { 2 - 4 } & 3 & 72 & Extention \\
\hline 1 & 20 & 72 & Final Extention \\
\hline
\end{tabular}

\section{Results and Discussion}

Out of 110 urine samples collected from children under five years old, from Baghdad hospitals. 72 Escherichia coli isolates were identify and characterize according to certain morphological, cultural and biochemical tests as described by (11), the identification results were confirmed using ApiE20.Table(1) showed that the infection in urinary tract of female were 39 isolates $54.2 \%$ of and that of males were 33 isolates $45.8 \%$. result show that females had tendency to get UTI more than males, this due to the anatomy and femal have a shorter urethra than male, they are 14 times more likely to suffer from an ascending UTI(12). This result was agreed with (13) that E.coli is the major causative agent in humen UTI. This study showed that children under two years infected more than older age due to many reasons, the more important, defect in immune system and infant artificial suckling (12)

Table 5: Number and percentage of E. coli isolates

\begin{tabular}{|c|c|c|}
\hline Sex & No. of E.coli isolates & $\%$ \\
\hline Male & 33 & $45.8 \%$ \\
\hline Female & 39 & $54.2 \%$ \\
\hline Total & 72 & $100 \%$ \\
\hline
\end{tabular}

\section{Genotypic detection of isolates}

PCR technique is a primer mediated enzymatic amplification of specifically cloned or genomic DNA sequences. PCR has become fast reliable assay for molecular biology based diagnosis of the variety of many diseases, because of its speed and versatility. In present study PCR technique was used to detect genes responsible for fimbrial adhesive system. The DNA of 72 E.coli isolates was extracted and detected by electrophoresis on $1 \%$ agarose and exposed to UV light in which the DNA appered as compact bands figure(1).

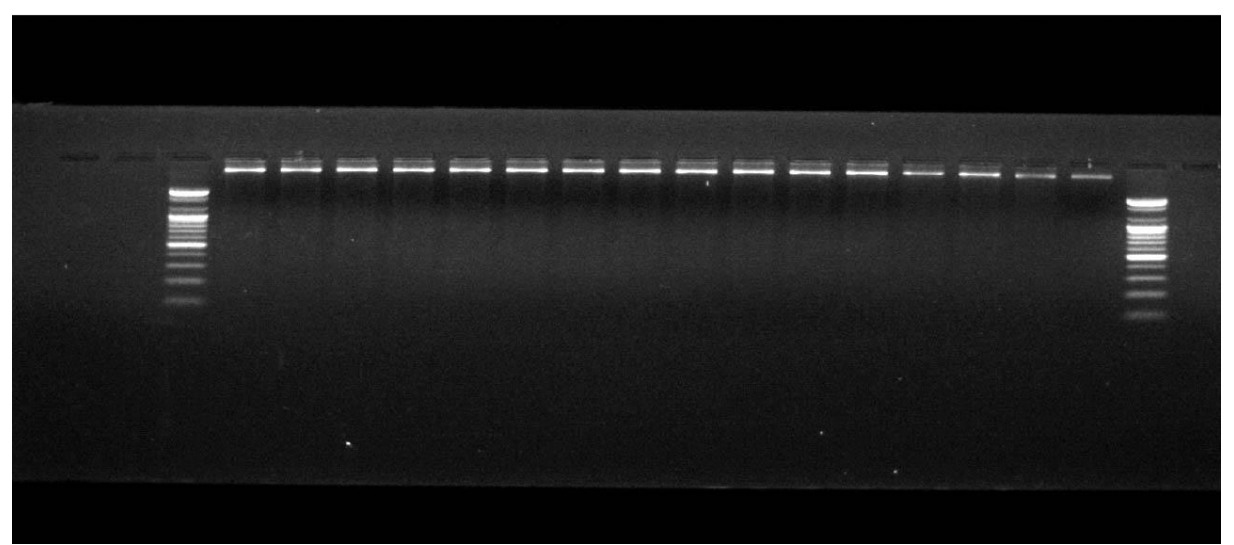

Figure 1: Total genomic DNA extracted from E.coli isolates using 1\% agarose gel electrophoresis 70 volt, 1.5 hour

Detection of $\operatorname{Fim}(\boldsymbol{H})$ gene:

All 72 E.coli isolates were genotypically characterized by the use of PCR assay, for virulence factor encoding FimH. Polymerase chain reaction showed $100 \%$ positive result ,gave clear bands of the same amplified FimH gene, on $1 \%$ agarose gel as a result of PCR reaction Figure (2), the size of the amplified gene FimH gene was 508 bp. As compared with 100 bp DNA ladder which represents the whole size of FimH gene and other virulence gene since it was picked up from the upstream and downstream region of the

\section{Volume 6 Issue 7, July 2017 www.ijsr.net}




\section{International Journal of Science and Research (IJSR) \\ ISSN (Online): 2319-7064 \\ Index Copernicus Value (2015): 78.96 | Impact Factor (2015): 6.391}

gene(14).This study agreed with $(10,15 \& 16)$ found $100 \%$ of E.coli isolates were positive for FimH adhesive gene which was the most prevalent virulence factor detected, also agreed with(17)and(18) found that $95 \%, 92 \%$ of E.coli isolates were positive for Fim $H$ gene respectively.(19) and(13) found $71 \%, 68 \%$ of E.coli isolates only have FimH gene respectively, whlile our study is agreement with(20) found
98\% of E.coli isolated from children with UTI. FimH mediated adherence by enhancing the inflammatory response and contribute to colonization of the bladder and initiate infection by binding to the superficial bladder epithelial cells that line the luminal surface of the bladder(11).

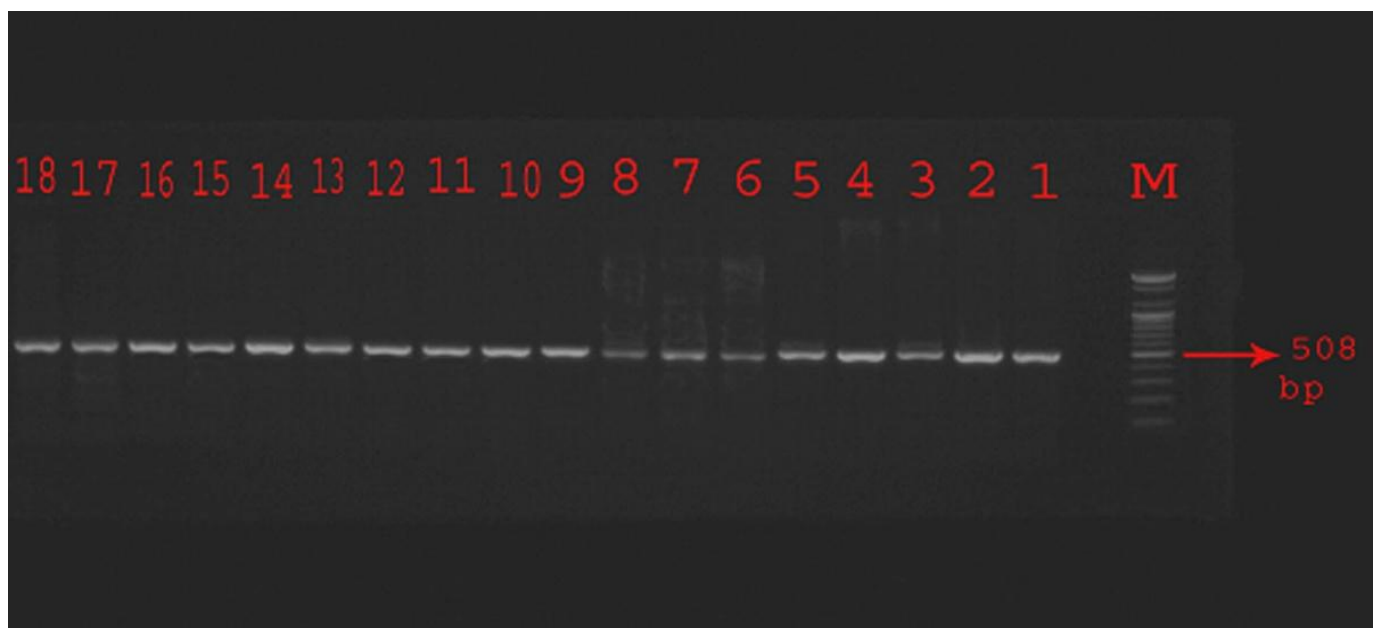

Figure 2: Agarose gel electrophoresis (1\% agarose, 70 volt, for 1.5 hour) and Ethidium bromide staining to detect Fim(H) gene size product(band508bp)

\section{Detection of Pap (G) alleles I II III}

Atotal of 72 E.coli isolated from UTI children patients were detected for virulence factor encoding $\operatorname{Pap}(G)$ alleles by PCR technique.Results from polymerase chain reaction showed that the prevalence of virulent genes PapG I occurred in 14 isolates19.4\%, Figure(3), results for PapG III occurred in28 E.coli isolates38.8\%, Figure(4), while result detection for $P a p G$ II showed negative for this gene for all E.coli isolates.(21) found the prevalence of PapG I
$6 \%$ and G II 30\% in E.coli isolates, but in the study of(22) showed that PapG III detected in $27 \%$ and PapG II $7 \%$ of E.coli isolated from urinary tract infection, while (10) found that the prevalence of PapG II in $32.7 \%$ E.coli isolates from urine samples.PapG fimbrial adhesion recognize in adhering to uroepithelial cells in urinary tract and endothelial cells on receptor Gal $(\propto 1-4)$,mediating bacterial adherence and initiate infection.

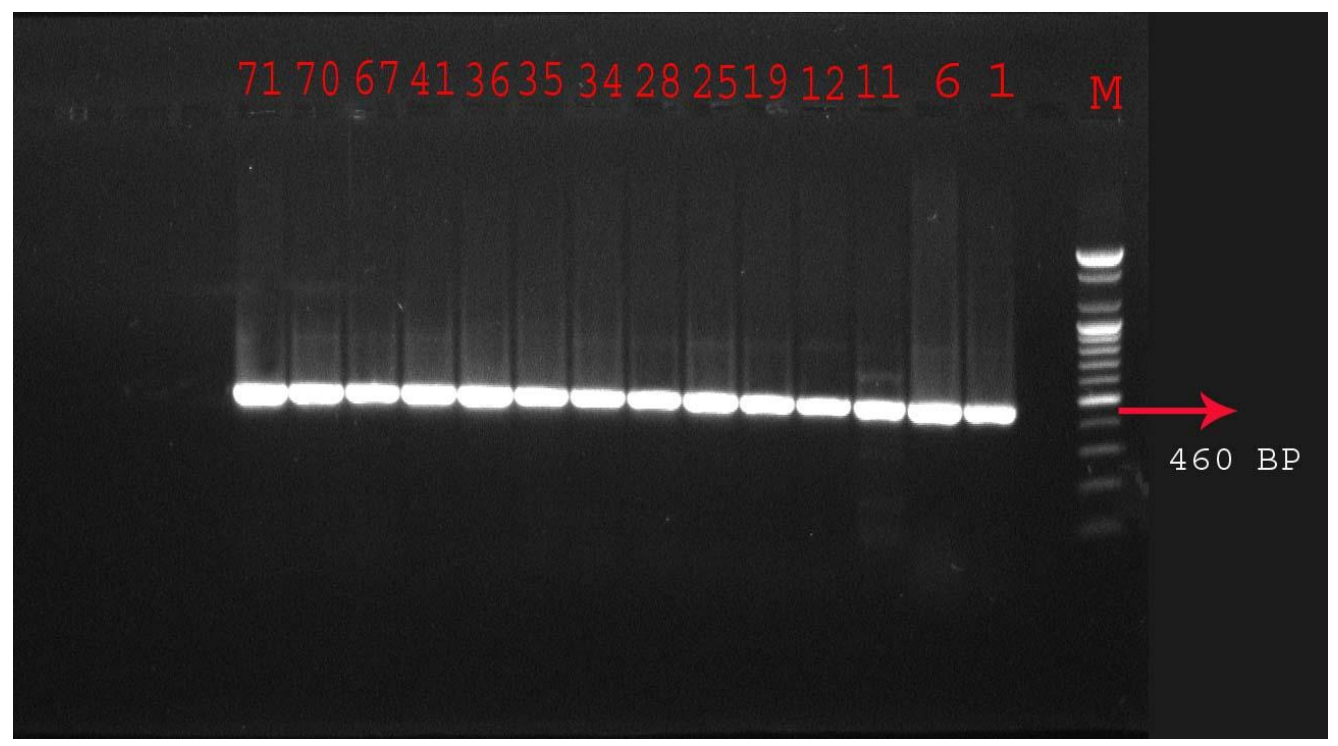

Figure 3: Agarose gel electrophoresis (1\% agarose, 70 volt, for 1.5 hour) and Ethidium bromide staining to detect PapG I gene size product(band460bp).

Volume 6 Issue 7, July 2017 www.ijsr.net 


\section{International Journal of Science and Research (IJSR) ISSN (Online): 2319-7064}

Index Copernicus Value (2015): 78.96 | Impact Factor (2015): 6.391

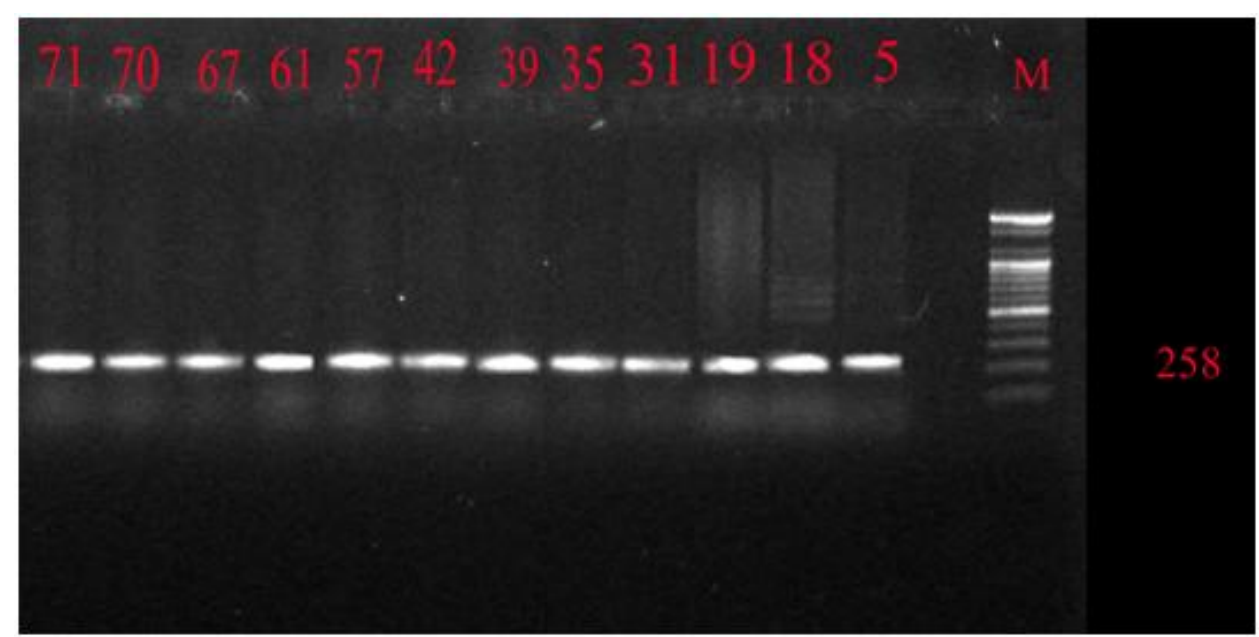

Figure 4: Agarose gel electrophoresis(1\% agarose, 70 volt, for 1.5 hour) and Ethidium bromide staining to detect PapG III gene size product(band258bp)

$\mathrm{P}$ Fimbriae, the principal mannose-resistant adherence organelles of extraintestinal pathogenic Escherichia coli, are known to contribute to pathogensis by promoting bacterial colonization of host tissues and by stimulating an injurious host inflammatory response(23) E.coli causes the vast majority of UTI in both ambulatory and hospitalized patients(13).The degree of severity depends on the virulence of the responsible strains and on the susceptibity of the host, particularly if there is a concomitant urological illness (24). Genes coding for fimbrial adhesive systems represent the most common factors for the virulence of E.coli in UTI.The distribution of these genes in our strains is in agreement with other published data (25). Our results show a higher frequency of fimH compared with the rest of the genes, which may indicate a crucial role of the virulence genes in E.coli causing UTI. Regarding P fimbriae, our results were in agreement with those of many studies, indicating that among patients with acute Pyelonephritis and cystitis, posses P fimbriae(13). Moreover an important role of pap adhesion genes in the pathophysiology of pyelonephritis caused by E.coli has been reported in several studies (26).

In conclusion, our study showed, a high variability was found among UPEC isolates regarding the distribution of virulence genes and futher studies are needed to identify E.coli virulence factors responsible for UTI in children under five years and to determine the physiopathology of these infections of these infections to consider possible prevention measures and means.

\section{References}

[1] Todar, K.(2008). Pathogenic E.coli. University of Wisconsim -Madisan Department of Bacteriology.Todar's Online Textbook of Bacteriology .

[2] Zhanal, G.; Hisanaga, T. and Laing, N.(2006).Antibiotic resistance in Escherichia coli outpatient urinary isolates : final results from the North American Urinary Tract Infection collaborative Alliance(NAUTICA). Int. J. Antimicrob Agents. 27,pp.468-475.

[3] Johnson, J.R.(1991).Virulence factors in Escherichia coli urinary tract infection. Clin. Microbiol.Rev. 4, pp. 80-118.
[4] Licznar, P.; Eychenne, I.; Azema, C.; Decramer, S.; Bouissou, F. and Fayat, O.(2003).Revised prevalence of afa+ Escherichia coli strains in acute pyelonephritis of children. Pathol Biol(paris). 51, pp.512-515.

[5] Giron, J.A.(1996) : Fimbriae of enteropathogenic Escherichia coli. Rev. Microbiol. Sao Paulo. 27 ( sup.1) : 72-76.

[6] Greenwood, D. ; Slack, R.C. and Peutherer, J.F.(2002). Med. Microbiology . $6^{\text {th }}$ ed . Churchill Livingstone. Inc .

[7] Johnson,J.R. and Stell,A.L.(2000).Extended virulence genotypes of Escherichia coli strains from patients with urosepsis in relation to phylogeny and host compromise.J. Infect.Dis. 181, pp.251-272.

[8] Mihaylova , M. ;Kostadinova,S. and Marhova, M. (2012).Distribution of virulence determinants and biofilm-forming among clinical urinary isolates, $\mathrm{J}$. Bio.Sci. Biotech., SE/ONLINE: 45-51.

[9] Chess, T.(2012) Microb.18 ${ }^{\text {th }}$ edition.McGrowHill.United States.

[10] Al-Mayahie, Sareaa. M.Gatya. (2013) Vaginal Colonization by papG Allele $\mathrm{II}^{+}$Escherichia coli Isolates from Pregnant and Nonpregnant Women as Predisposing Factor to Pyelonephritis . Inf. Dis. Obstetrics Gynecology Article ID 860402, 6 pages .

[11] Kaper, J.B. ; Nataro, J.P. and Mobley, H.L.(2004). Pathogenic Escherichia coli . Nat. Rev. Microb., 2(2):123-140 .

[12] Cavagnaro, F. (2005).Urinary tract infection in childhood . Clin. Microb. 18: 417 -422.

[13] Mouna, T.; Asma, F.; Ben-selma, W.and Boukdida, J.(2013).Distribution of uropathogenic virulence genes in Escherichia coli isolated from patients with urinary tract infection. Inter.J.of Infect.Dis. 17, pp.450-457.

[14] Ribeiro,T.M.;Yano.T. \&Silva.L,D.(2008).Genotypic characterization of virulence factors in Escherichia coli strains from patients with cystitis. Rev. Inst. Med.trop.S.Paulo.50(5):255-260.

[15] Abed, Z. A. (2013) . Identification of Some UTI Causative Agents Using Cultural and Molecular Methods and Their Correlation with Interleukin-8 in Children Patients. M.SC. Thesis. College of Science for Women/ University of Baghdad .

[16] Johnson, JR. and Stell, Al. (2000) . Extended Virulence genotypes of Escherichia coli strain from patients with

\section{Volume 6 Issue 7, July 2017 www.ijsr.net}




\section{International Journal of Science and Research (IJSR) \\ ISSN (Online): 2319-7064 \\ Index Copernicus Value (2015): 78.96 | Impact Factor (2015): 6.391}

urosepsis in relation to phylogeney and host compromise. J. Infect. Dis. 181(1):261-72 .

[17] Ananias, M. and Yano, T. (2008). Serogroups and virulence genotypes of Escherichia coli isolated from patients with sepsis. Braz. J. Med. Bio. Res., 41 (10) : 877-883.

[18] Wang, M.C.; Tseng, C.C.; Chen, C.Y.; Wu, J.J. and Huang J.J. (2002). The Role of Bacterial Virulence and Host Factors in Patients with Escherichia coli Bacteremia Who Have Acute Cholangitisor Upper Urinary Tract Infection. E. coli Virulence and Host Factors in AC • CID 2002:35. 1161.

[19] Abass, S. K.; Ali, M.R. ; Authman, S.H. ( 2014) . Isolated of multi Antibiotics Resistance Escherichia coli from urinary tract infection and the Detection of Pap C and Fim $H$ virulence genes by polymerase chain reaction technique. Diyala J. pure sci ., 10 (1 ) : 112127 .

[20] Usein, C.R.; Grigore,L.A.; Georgescu, R.M.; Bãltoiu, M.C.; Condei, M. and Teleman, M.D. (2001). Phylogenetic background and extraintestinal virulence genotypes of Escherichia coli vaginal strains isolated from adult women Genotipurile de virulenţă extraintestinală şi încadrarea filogenetică a tulpinilor vaginale de Escherichia coli izolate de la femei adulte. Revista Română de Medicină de Laborator Vol. 19, Nr. 1/4, Martie .

[21]Féria. C .; Machado, J.; Duarte Correia, J.; Gonçalves, J.; Gaastra W.(2001). Distribution of papG alleles among uropathogenic Escherichia coli isolated from different species. FEMS Microbiol Letter. $21 ; 202(2): 205-8$.

[22] Johnson, J.R.; J.L. Swanson; T.J.Barela; and J.J.Brown (1997). Receptor specific of variant Gal ( $\propto 1-4)$ Galbinding pp $\mathrm{G}$ adhesions of uropathogenic Escherichia coli as assessed by hemagglutination phenotypes. J. Infec. Dis., 175:373-81.

[23] Kuehn, M.J.; Jacob-Dubuission, F. and Dodson, K.(1994). Genetic, biochemical, and structural studies of biogenesis of adhesive pili in bacteria. Meth. Enzyme., 236: 282-306.

[24] Soto,S.M.; Zuniga,S.; Uleryd,P. and Vita,J.(2011).Acquistion of pathogenicity island in an Escherichia coli clinical isolates causing febrile urinary tract infection.Eur.J.Clin.Microbiol.Infect.Dis.10, pp.1258-1262.

[25] Codrufa-Romantia, U.; Damian,M.; Tatu-Chiton,D.; Capusa,C.; Fagara, R. and Tudorache, D.(2001).Prevalence of virulence genes in Escherichia coli strains isolated from Romanian adult urinary tract infection cases. J.Cell.Mol.Med. 5, pp.303-310.

[26] Shohreh, F. and Fatemeh, E.(2009). The prevalence of virulence genes of Escherichia coli strains isolated from children with urinary tract infection. Saudi J.Kidney Dis. Transpl. 20 ,pp.613-617. 